\title{
EFFECT OF HUMIC ACID AND CHITOSAN ON GROWTH AND YIELD OF OKRA (ABELMOSCHUS ESCULENTUS L.) UNDER SALINE CONDITIONS
}

\author{
Ramadan, Mansour E.* and Mohamed M.A. El Mesairy \\ Department of Plant Production, Desert Research Center, El- \\ Matareya, Cairo, Egypt \\ *E-mail: ramadandrc79@gmail.com
}

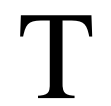

he present study was carried out in two successive seasons of 2013 and 2014 at the Experimental Farm, Desert

Research Center, Ras Sudr Region, South Sinai Governorate, Egypt, to study the effect of addition of humic acid (potassium humate) at the rates $0,2,4$ and $6 \mathrm{~kg} / \mathrm{fed}$ and foliar application of chitosan rates $(0,100,150$ and $200 \mathrm{ppm})$ on growth, yield and quality as well as chemical constituents of okra plants El Balady cultivar. Results showed that okra plants grown with humic acid at $6 \mathrm{~kg} / \mathrm{fed}$ or chitosan at $200 \mathrm{ppm}$ had the highest height, number of leaves, fresh and dry weight per plant, leaf minerals $(\mathrm{N}, \mathrm{P}$ and $\mathrm{K}$ ), fruit number/plant, mean fruit fresh weight, plant yield, total yield/fed, total protein, $\mathrm{P}$ and $\mathrm{K}$ values of fruit and the least dietary fiber of fruit as compared to other treatments. The highest productivity of okra under Ras Sudr conditions could be obtained by application of $6 \mathrm{~kg}$ humic acid per feddan combined with $200 \mathrm{ppm}$ chitosan.

Keywords: okra plants, potassium humate, chitosan, productivity, mineral contents

Okra (Abelmoschus esculentus L.) is known as lady's finger of Malvaceae family and is one of the most important summer vegetable in Egypt. It is a good source to fulfill the energy requirements of the body. It also provides vitamin $\mathrm{A}, \mathrm{B}, \mathrm{C}$, protein, amino acids, minerals and iodine (Hossain et al., 2006). Okra cultivation is hampered in saline soil as it is sensitive to salinity (Ashraf et al., 2003). Humic acid and chitosan could be used in order to obtain some level of salinity tolerance.

Humic acid is complex substances derived from organic matter decomposition, that is the most significant constituents of organic matter in both soils and municipal waste compost, and have a relevant role in the cycling of many elements in the environment and in soil ecological functions (Senesi et al., 1996). Humic acid may play a major role in the plant growth under different soil condition. The positive effects of humic acid on the 
growth (plant height, leaf number/plant, plant fresh and dry weight), protein and mineral percent (N, P and K) of some plants such as cowpea (El Hefny, 2010), potato (Rizk et al., 2013), okra (Kandil et al., 2015) and garlic (Shafeek et al., 2015) have been reported. Meanwhile, fiber content was decreased with addition of humic acid (El Bassiony et al., 2010 on snap bean). There are many studies that also looked at the effect of humic acid on the yield and its components such as fruit number and weight (Rizk et al., 2013 on potato; Abu Zinada and Sekh Eleid, 2015 on potato; Farnia and Moradi, 2015 on tomato; Kandil et al., 2015 on okra), which reported that yield and its components were increased with humic acid addition.

The Chitosan belongs to the carbohydrate family which contains unramified chains formula; originally formulated from the glucose circle, however, it contains a group of free amino, carbon atomnum2 (called glucose amino) which is similar to cellulose. Chitosan can be extracted from the marine crustacean like shrimps, cramp, and pinfish or from the exoskeletons of most insects under the name of chitin which can be transformed into Chitosan by extracting the Acetyl group and turn it into amino (Falk et al., 1966 and Sugiyama et al., 2001). Chitosan is a natural biopolymer containing a lot of nitrogen molecules that enhance germination index, shoot and root dry weight (Guan et al., 2009); can increase the microbial population by large numbers, and transforms organic nutrient into inorganic nutrients that are easily absorbed by plant roots (Samashekar and Joseph, 1996; Bolot et al., 2004). Numerous studies have reported the ability of chitosan to increase plant growth (height, leaf number, fresh and dry weight), yield components (fruit number/plant, fruit weight and total yield) and plant contents of $\mathrm{N}, \mathrm{P}$ and $\mathrm{K}$ in different plant species cultivated under diverse growth conditions (Abdel Mawgoud et al., 2010 on strawberry; Shehata et al., 2012 on cucumber; Abd El Gawad and Bondok, 2015 on tomato). Moreover, Mondal et al. (2012) found that foliar application of chitosan at rates of 100 or $125 \mathrm{ppm}$ led to a maximum plant growth (height, leaf number and dry mass), fruit number/plant, fruit weight and fruit yield in okra plant. In addition, foliar spray with chitosan at rate of $200 \mathrm{ppm}$ increased plant growth (height, leaf number, fresh and dry weight), yield, N, $\mathrm{P}, \mathrm{K}$ and protein percent of shoot and seed of common bean plant (Abu Muriefah, 2013). The aim of this study was to investigate the effect of humic acid and chitosan on vegetative growth, yield and quality of okra plant under saline conditions.

\section{MATERIALS AND METHODS}

The field experiment was carried out in a Ras Sudr station farm in south Sinai governorate, Egypt, during the two successive seasons of 2013 and 2014. Seeds of okra El Balady cultivar were sown on March 15 and 20 
of 2013 and 2014 seasons, respectively. Plants were spaced at $50 \mathrm{~cm}$ apart. All agricultural practices of cultivation were performed as recommended by the Ministry of Agriculture, Egypt. The soil texture was characterized as sandy loam, highly calcareous and saline. The mechanical and chemical analyses of the experimental soil are presented in table (1). The soil analysis was carried out according to Richards (1954), Black and Editor (1965) and Jackson (1967). The experiment was irrigated by saline water pumped from a well (4500 ppm).The drip irrigation method was used in the experiment. The analysis of irrigation water is given in table (2).

Table (1). Mechanical and chemical properties of the experimental soil.

\begin{tabular}{|c|c|c|c|c|c|c|c|c|}
\hline $\begin{array}{r}\text { Depth } \\
\text { (cm) }\end{array}$ & pH & $\begin{array}{c}\text { EC } \\
d S / m^{2}\end{array}$ & $\mathrm{CaCO}_{3} \%$ & Silt \% & Sand $\%$ & Clay \% & & $\begin{array}{l}\text { Texture } \\
\text { Class }\end{array}$ \\
\hline $0-30$ & 7.7 & 8.65 & 56.99 & 8.05 & 81.28 & 10.67 & & Sandy \\
\hline \multirow[t]{3}{*}{$30-60$} & 7.4 & 7.90 & 52.48 & 7.59 & 86.08 & 6.33 & & loam \\
\hline & \multicolumn{4}{|c|}{ Soluble anions (meq/100g) } & \multicolumn{4}{|c|}{ Soluble cations (meq/100g) } \\
\hline & $\mathrm{CO}_{3}{ }^{-2}$ & $\mathrm{HCO}_{3}^{-}$ & $\mathrm{SO}_{4}{ }^{-2}$ & $\mathrm{Cl}^{-}$ & $\mathbf{C a}^{+2}$ & $\mathbf{M g}^{+2}$ & $\mathrm{Na}^{+}$ & $\mathbf{K}^{+}$ \\
\hline $0-30$ & 0.00 & 5.83 & 10.53 & 31.14 & 23.82 & 10.84 & 10.83 & 2.01 \\
\hline $30-60$ & 0.00 & 2.96 & 16.20 & 21.50 & 16.87 & 6.00 & 17.70 & 0.09 \\
\hline
\end{tabular}

Table (2). Chemical analysis of the irrigation water.

\begin{tabular}{cccccccccc}
\hline \multirow{2}{*}{$\mathbf{p H}$} & $\begin{array}{c}\mathbf{E C} \\
\mathbf{d S} / \mathbf{m}^{2}\end{array}$ & \multicolumn{4}{c}{ Soluble anions (meq/l) } & \multicolumn{3}{c}{ Soluble cations (meq/l) } \\
\cline { 3 - 10 } & $\mathbf{C O}_{3}^{-2}$ & $\mathbf{H C O}_{3}^{-}$ & $\mathbf{S O}_{\mathbf{4}}^{-2}$ & $\mathbf{C l}^{-}$ & $\mathbf{C a}^{+2}$ & $\mathbf{M g}^{+2}$ & $\mathbf{N a}^{+}$ & $\mathbf{K}^{+}$ \\
\hline 8.6 & 7.03 & 0.00 & 2.63 & 21.30 & 39.94 & 5.10 & 13.50 & 45.15 & 0.12 \\
\hline
\end{tabular}

The experiment was designed as split plot design with three replications. Every replicate included 16 treatments which were the combinations between four levels of both humic acid and chitosan. The main plots were devoted to the humic acid, while the sub plots were occupied with the chitosan. The experimental unit area was $12 \mathrm{~m}^{2}$ and contained 4 rows each with $4 \mathrm{~m}$ length and $75 \mathrm{~cm}$ width. The distance between drippers was 50 $\mathrm{cm}$.

\section{The Experimental Treatments}

- Humic acid application rates: humic acid in a solid form as potassium humate (85\%) at the rates of 0 (without), 2, 4 and $6 \mathrm{~kg} / \mathrm{fed}$, which were added with irrigation water at three times, started after 20 days from sowing, with 10-day intervals. 
- Chitosan spraying rates were 0 (control), 100, 150 and $200 \mathrm{ppm}$. Spraying treatments were started after 20 days of sowing at three times with 10-day intervals.

\section{Data Recorded}

\subsection{Plant growth}

Random samples, each, of three plants were taken after 60 days from sowing from each experimental plot to determine plant height number of leaves, fresh and dry weights per plant. The plants were dried in an electric oven at $70^{\circ} \mathrm{C}$ to constant dry weight.

\subsection{Mineral content of leaves}

Nitrogen and phosphorus concentrations were determined using modified micro Kjeldahl and colorimetric methods, respectively, according to the procedure described by Cottenie (1980). Potassium concentration was measured using flame photometer method (Jenway, PFP-7, ELE Instrument Co. Ltd., UK) as described by Chapman and Pratt (1982).

\subsection{Fruit yield and its components}

Okra fruits at marketable stage were harvested twice weekly. At harvest, number of fruits/plant, mean fresh weight of fruit, total yield (per plant and feddan) were recorded.

\subsection{Nutritional status of fruit}

Total protein and dietary fiber were determined according to A.O.A.C. (1995). Phosphorus concentration was determined according to the procedure described by Cottenie (1980), and potassium concentration was as described by Chapman and Pratt (1982)

\section{Statistical Analysis}

All data were analyzed statistically following the analysis of variance (ANOVA) and the mean differences were adjusted with Duncan's test at a 0.05 level of significance (Steel, 1960), using the statistical computer package program, COSTAT.

\section{RESULTS AND DISCUSSION}

\section{Vegetative Growth}

Results revealed that humic acid application significantly increased plant growth characteristics (height, leaf number, fresh and dry weight) in both seasons (Table 3). The effect being more pronounced with the highest rate of humic acid. These results confirm those of Kandil et al. (2015) and Shafeek et al. (2015). The satisfactory stimulation of plant growth may be due to the role of humic acid as a positive effect on solubility and uptake of micronutrients, also involved in uptake of other nutrients and can increase 
root and shoot growth and resistance to different stress factors (Ozkutlu et al., 2006). Humic acid applied to growing plants makes soil more fertile and productive, helps plants to resist drought, and increases the water holding capacity of soil. Humic acid improves drainage and increases aeration of the soil (Khristeva, 1953).

Table (3). Effect of humic acid and chitosan on growth parameters (plant height, leaf number, fresh and dry weight/plant) of okra plants after 60 day from sowing in 2013 and 2014 seasons.

\begin{tabular}{|c|c|c|c|c|c|c|c|c|c|}
\hline \multicolumn{2}{|c|}{ Treatments } & \multirow{2}{*}{\multicolumn{2}{|c|}{$\begin{array}{l}\text { Plant height } \\
(\mathbf{c m})\end{array}$}} & \multirow{2}{*}{\multicolumn{2}{|c|}{$\begin{array}{c}\text { Leaf } \\
\text { number/plant }\end{array}$}} & \multirow{2}{*}{\multicolumn{2}{|c|}{$\begin{array}{c}\text { Fresh } \\
\text { weight/plant (g) }\end{array}$}} & \multirow{2}{*}{\multicolumn{2}{|c|}{$\begin{array}{c}\text { Dry weight/plant } \\
\text { (g) }\end{array}$}} \\
\hline \multirow{2}{*}{$\begin{array}{c}\text { Humic } \\
\text { acid } \\
\text { (kg/fed) }\end{array}$} & \multirow{2}{*}{$\begin{array}{c}\text { Chitosan } \\
\text { (ppm) }\end{array}$} & & & & & & & & \\
\hline & & 2013 & 2014 & 2013 & 2014 & 2013 & 2014 & 2013 & 2014 \\
\hline 0 & & 49.01 & 45.51 & 13.10 & 16.78 & 147.07 & 163.64 & 27.18 & 30.81 \\
\hline 2 & & 49.71 & 46.21 & 13.33 & 19.19 & 167.37 & 177.88 & 30.45 & 33.62 \\
\hline 4 & & 55.38 & 50.79 & 16.22 & 20.06 & 178.33 & 198.41 & 32.41 & 37.54 \\
\hline \multirow[t]{6}{*}{6} & & 58.95 & 55.45 & 18.37 & 22.14 & 193.83 & 227.26 & 36.11 & 42.94 \\
\hline & 0 & 49.21 & 45.71 & 14.02 & 17.36 & 153.60 & 174.53 & 28.64 & 32.65 \\
\hline & 100 & 50.80 & 47.26 & 15.19 & 19.31 & 168.42 & 186.54 & 30.88 & 35.26 \\
\hline & 150 & 55.31 & 50.92 & 15.64 & 20.11 & 176.86 & 197.79 & 32.12 & 37.46 \\
\hline & 200 & 57.73 & 54.06 & 16.17 & 21.39 & 187.72 & 208.33 & 34.52 & 39.53 \\
\hline & $\mathbf{0}$ & 45.76 & 42.26 & 12.39 & 14.77 & 132.82 & 152.23 & 24.88 & 28.11 \\
\hline \multirow{4}{*}{$\mathbf{0}$} & 100 & 45.70 & 42.20 & 13.00 & 16.78 & 143.85 & 162.09 & 26.51 & 30.11 \\
\hline & 150 & 51.83 & 48.33 & 13.44 & 17.55 & 152.69 & 167.20 & 28.04 & 32.07 \\
\hline & 200 & 52.74 & 49.24 & 13.55 & 18.00 & 158.9 & 173.02 & 29.30 & 32.95 \\
\hline & $\mathbf{0}$ & 47.21 & 43.72 & 12.59 & 16.89 & 151.99 & 165.39 & 27.95 & 30.51 \\
\hline \multirow{4}{*}{2} & 100 & 49.16 & 45.67 & 13.11 & 18.44 & 163.98 & 174.40 & 30.05 & 33.26 \\
\hline & 150 & 51.00 & 47.50 & 13.72 & 19.44 & 173.71 & 181.96 & 30.94 & 34.88 \\
\hline & 200 & 51.47 & 47.93 & 13.89 & 22.00 & 179.79 & 189.76 & 32.84 & 35.82 \\
\hline & $\mathbf{0}$ & 51.55 & 48.10 & 14.78 & 17.66 & 156.60 & 178.98 & 28.93 & 33.99 \\
\hline \multirow{4}{*}{4} & 100 & 54.21 & 50.60 & 16.33 & 20.11 & 179.84 & 189.19 & 32.26 & 36.00 \\
\hline & 150 & 57.83 & 50.67 & 16.56 & 20.78 & 185.78 & 203.12 & 33.48 & 37.86 \\
\hline & 200 & 57.92 & 53.77 & 17.22 & 21.67 & 191.11 & 222.36 & 34.98 & 42.30 \\
\hline & $\mathbf{0}$ & 52.31 & 48.77 & 16.33 & 20.11 & 172.98 & 201.51 & 32.80 & 37.99 \\
\hline \multirow{3}{*}{6} & 100 & 54.13 & 50.57 & 18.33 & 21.89 & 186.02 & 220.49 & 34.70 & 41.66 \\
\hline & 150 & 60.57 & 57.17 & 18.83 & 22.66 & 195.24 & 238.86 & 36.00 & 45.04 \\
\hline & 200 & 68.80 & 65.30 & 20.00 & 23.89 & 221.07 & 248.18 & 40.95 & 47.06 \\
\hline \multicolumn{10}{|c|}{ L.S.D at $5 \%$ for } \\
\hline \multicolumn{2}{|c|}{ Humic acid } & 5.42 & 2.77 & 0.32 & 0.22 & 0.68 & 0.83 & 0.32 & 2.32 \\
\hline \multicolumn{2}{|l|}{ Chitosan } & 2.79 & 2.41 & 0.26 & 0.32 & 0.54 & 0.79 & 0.30 & 1.63 \\
\hline \multicolumn{2}{|c|}{ Interaction } & N.S. & 4.83 & 0.51 & N.S. & 1.08 & 1.59 & 0.60 & N.S. \\
\hline
\end{tabular}


Concerning chitosan, all treatments significantly affected all growth characteristics in both seasons and the most effective treatment for enhancing the plant height, leaf number, fresh and dry weight per plant was the highest chitosan level. Similar results were reported by Mondal et al. (2012) and Abd El Gawad and Bondok (2015). The favorable effects of chitosan on growth of okra plants may be attributed to that the application of chitosan increased key enzyme activities of nitrogen metabolism and improved the transportation of nitrogen in the functional leaves which enhanced plant growth and development (Khan et al., 2002; Chibu and Shibayama, 2003; Gornik et al., 2008), also, chitosan stimulate plant growth by enhancing cell division similar to gibberellins ( $\mathrm{Al}$ ahmadi, 2015).

As for the interaction between humic acid and chitosan levels, generally, the most vigorous plants were those received the highest humic acid and chitosan levels. The differences among treatments were significant in both seasons, except plant height in the first season, leaf number and dry weight/plant in the second season.

\section{Mineral Content of Leaves}

Leaf percentages of $\mathrm{N}, \mathrm{K}$ and $\mathrm{P}$ were increased significantly as humic acid application was increased in both seasons (Table 4). Similar results were found by El Hefny (2010). The simulative effect of humic acid on mineral uptake might be due to being associated with its chelating power of nutrients along with its impact on physicochemical and biological properties of soil (Sharif, 2002 and Khaled and Fawy, 2011). In addition, humic acid as a good manure state causing more availability for the nutrients in the soil by lowering soil $\mathrm{pH}$ value through yielding intermediate organic acid (Sharif, 2002), as well as, increasing the activity of soil organisms to liberate more nutrients from the unavailable reserves led to increase available nutrients (Bama et al., 2003 and Eid, 2011).

The leaf percentages of $\mathrm{N}, \mathrm{K}$ and $\mathrm{P}$ were significantly the highest in okra plants provided with chitosan at $200 \mathrm{ppm}$ and were the lowest in control plants. Our results are in agreement with those of Shehata et al. (2012) and Abu Muriefah (2013). The effect of chitosan on leaf minerals may be attributed to the increase in microbial population by large numbers, and transform organic nutrient into inorganic nutrients that are easily absorbed by plant roots (Samashekar and Joseph, 1996 and Bolot et al., 2004).

The application of $6 \mathrm{~kg}$ humic acid/fed combined with $200 \mathrm{ppm}$ chitosan resulted in increasing the percentages of $\mathrm{N}, \mathrm{P}$ and $\mathrm{K}$ in leaves more than other treatments. These results were significant in both seasons, except $\mathrm{N}$ percentage in the first season.

Egyptian J. Desert Res., 65, No. 1, 47-60 (2015) 
Table (4). Effect of humic acid and chitosan on N, P and K percentages of okra leaves in 2013 and 2014 seasons.

\begin{tabular}{|c|c|c|c|c|c|c|c|}
\hline \multicolumn{2}{|c|}{ Treatments } & \multirow{2}{*}{\multicolumn{2}{|c|}{$\mathbf{N}$}} & \multirow{2}{*}{\multicolumn{2}{|c|}{$\mathbf{P}$}} & \multirow{2}{*}{\multicolumn{2}{|c|}{$\mathbf{K}$}} \\
\hline \multirow{2}{*}{$\begin{array}{l}\text { Humic } \\
\text { acid } \\
\text { (kg/fed) }\end{array}$} & \multirow{2}{*}{$\begin{array}{c}\text { Chitosan } \\
\text { (ppm) }\end{array}$} & & & & & & \\
\hline & & 2013 & 2014 & 2013 & 2014 & 2013 & 2014 \\
\hline 0 & & 1.41 & 1.52 & 0.28 & 0.28 & 1.49 & 1.56 \\
\hline 2 & & 1.55 & 1.70 & 0.30 & 0.33 & 1.56 & 1.71 \\
\hline 4 & & 1.58 & 1.86 & 0.36 & 0.37 & 1.62 & 1.78 \\
\hline \multirow[t]{6}{*}{6} & & 1.74 & 2.01 & 0.42 & 0.45 & 1.75 & 1.93 \\
\hline & 0 & 1.38 & 1.57 & 0.29 & 0.31 & 1.50 & 1.64 \\
\hline & 100 & 1.51 & 1.75 & 0.33 & 0.35 & 1.59 & 1.74 \\
\hline & 150 & 1.65 & 1.85 & 0.35 & 0.38 & 1.63 & 1.78 \\
\hline & 200 & 1.74 & 1.92 & 0.39 & 0.40 & 1.70 & 1.83 \\
\hline & $\mathbf{0}$ & 1.24 & 1.37 & 0.24 & 0.26 & 1.44 & 1.49 \\
\hline \multirow{4}{*}{$\mathbf{0}$} & 100 & 1.32 & 1.46 & 0.27 & 0.26 & 1.48 & 1.55 \\
\hline & 150 & 1.48 & 1.58 & 0.28 & 0.28 & 1.50 & 1.58 \\
\hline & 200 & 1.58 & 1.67 & 0.33 & 0.31 & 1.54 & 1.62 \\
\hline & 0 & 1.28 & 1.45 & 0.25 & 0.28 & 1.48 & 1.60 \\
\hline \multirow{4}{*}{2} & 100 & 1.52 & 1.67 & 0.29 & 0.32 & 1.55 & 1.72 \\
\hline & 150 & 1.64 & 1.80 & 0.31 & 0.35 & 1.59 & 1.74 \\
\hline & 200 & 1.76 & 1.88 & 0.35 & 0.38 & 1.61 & 1.79 \\
\hline & 0 & 1.40 & 1.60 & 0.29 & 0.30 & 1.50 & 1.69 \\
\hline \multirow{4}{*}{4} & 100 & 1.52 & 1.87 & 0.34 & 0.37 & 1.61 & 1.78 \\
\hline & 150 & 1.66 & 1.95 & 0.39 & 0.40 & 1.65 & 1.81 \\
\hline & 200 & 1.74 & 2.01 & 0.40 & 0.42 & 1.73 & 1.85 \\
\hline & 0 & 1.59 & 1.86 & 0.37 & 0.38 & 1.57 & 1.77 \\
\hline \multirow{3}{*}{6} & 100 & 1.66 & 1.99 & 0.41 & 0.43 & 1.70 & 1.89 \\
\hline & 150 & 1.81 & 2.08 & 0.43 & 0.47 & 1.78 & 1.99 \\
\hline & 200 & 1.88 & 2.11 & 0.46 & 0.50 & 1.93 & 2.05 \\
\hline \multicolumn{8}{|c|}{ L.S.D at $5 \%$ for } \\
\hline \multicolumn{2}{|l|}{ Chitosan } & 0.05 & 0.03 & 0.01 & 0.01 & 0.03 & 0.01 \\
\hline \multicolumn{2}{|c|}{ Interaction } & N.S. & 0.07 & 0.01 & 0.02 & 0.05 & 0.02 \\
\hline
\end{tabular}

\section{Fruit Yield and its Components}

The highest rates of humic acid and chitosan gave the highest values of number of fruits/plant, mean fresh weight of fruit, plant yield and total yield/fed in the two growing seasons (Table 5). Similar findings were reported by Kandil et al. (2015) on humic acid and Mondal et al. (2012) on chitosan. 
Table (5). Effect of humic acid and chitosan on number of fruits/plant, mean fresh weight of fruit, plant yield and total yield of okra plants in 2013 and 2014 seasons.

\begin{tabular}{|c|c|c|c|c|c|c|c|c|c|}
\hline \multicolumn{2}{|c|}{ Treatments } & \multirow{2}{*}{\multicolumn{2}{|c|}{$\begin{array}{l}\text { Number of } \\
\text { fruits/plant }\end{array}$}} & \multirow{2}{*}{\multicolumn{2}{|c|}{$\begin{array}{l}\text { Mean fresh } \\
\text { weight of fruit } \\
\text { (g) }\end{array}$}} & \multirow{2}{*}{\multicolumn{2}{|c|}{$\begin{array}{c}\text { Plant yield } \\
\text { (g) }\end{array}$}} & \multirow{2}{*}{\multicolumn{2}{|c|}{$\begin{array}{l}\text { Total yield } \\
\text { (ton/fed.) }\end{array}$}} \\
\hline \multirow{2}{*}{$\begin{array}{l}\text { Humic } \\
\text { acid } \\
\text { (kg/fed) }\end{array}$} & \multirow{2}{*}{$\begin{array}{c}\text { Chitosan } \\
\text { (ppm) }\end{array}$} & & & & & & & & \\
\hline & & \multirow{2}{*}{$\begin{array}{c}\mathbf{2 0 1 3} \\
54.50\end{array}$} & \multirow{2}{*}{$\begin{array}{l}\mathbf{2 0 1 4} \\
55.58\end{array}$} & \multirow{2}{*}{$\begin{array}{c}\mathbf{2 0 1 3} \\
2.68\end{array}$} & \multirow{2}{*}{$\begin{array}{c}\mathbf{2 0 1 4} \\
2.70\end{array}$} & \multirow{2}{*}{$\begin{array}{c}\mathbf{2 0 1 3} \\
147.00\end{array}$} & \multirow{2}{*}{$\begin{array}{c}\mathbf{2 0 1 4} \\
150.79\end{array}$} & \multirow{2}{*}{$\begin{array}{c}\mathbf{2 0 1 3} \\
1.56\end{array}$} & 2014 \\
\hline 0 & & & & & & & & & 1.60 \\
\hline 2 & & 57.33 & 62.42 & 3.44 & 3.24 & 198.11 & 203.28 & 2.10 & 2.16 \\
\hline 4 & & 62.75 & 69.09 & 3.64 & 3.58 & 229.31 & 248.61 & 2.43 & 2.63 \\
\hline \multirow[t]{6}{*}{6} & & 65.34 & 71.75 & 3.82 & 3.91 & 250.96 & 281.70 & 2.66 & 2.99 \\
\hline & 0 & 55.08 & 59.75 & 2.91 & 2.90 & 161.78 & 175.63 & 1.72 & 1.86 \\
\hline & 100 & 58.33 & 63.42 & 3.38 & 3.33 & 198.76 & 213.97 & 2.11 & 2.27 \\
\hline & 150 & 61.58 & 66.84 & 3.58 & 3.50 & 221.77 & 236.85 & 2.35 & 2.51 \\
\hline & 200 & 64.92 & 68.83 & 3.71 & 3.71 & 243.08 & 257.92 & 2.58 & 2.73 \\
\hline & 0 & 49.33 & 50.67 & 2.29 & 2.34 & 112.95 & 118.45 & 1.20 & 1.26 \\
\hline \multirow{4}{*}{0} & 100 & 54.33 & 53.33 & 2.58 & 2.71 & 140.35 & 144.02 & 1.49 & 1.53 \\
\hline & 150 & 56.33 & 58.00 & 2.87 & 2.85 & 161.40 & 165.22 & 1.71 & 1.75 \\
\hline & 200 & 58.00 & 60.33 & 2.99 & 2.91 & 173.30 & 175.47 & 1.84 & 1.86 \\
\hline & 0 & 54.00 & 58.00 & 2.97 & 2.85 & 160.55 & 165.38 & 1.70 & 1.75 \\
\hline \multirow{4}{*}{2} & 100 & 56.00 & 61.00 & 3.50 & 3.24 & 196.25 & 197.75 & 2.08 & 2.10 \\
\hline & 150 & 57.33 & 63.67 & 3.54 & 3.25 & 202.85 & 206.68 & 2.15 & 2.19 \\
\hline & 200 & 62.00 & 67.00 & 3.75 & 3.63 & 232.80 & 243.30 & 2.47 & 2.58 \\
\hline & 0 & 57.00 & 64.00 & 3.17 & 3.07 & 180.50 & 196.67 & 1.91 & 2.08 \\
\hline \multirow{4}{*}{4} & 100 & 59.00 & 67.67 & 3.54 & 3.46 & 208.55 & 234.05 & 2.21 & 2.48 \\
\hline & 150 & 66.00 & 71.67 & 3.85 & 3.74 & 252.75 & 268.25 & 2.68 & 2.84 \\
\hline & 200 & 69.00 & 73.00 & 3.99 & 4.05 & 275.45 & 295.45 & 2.92 & 3.13 \\
\hline & 0 & 60.00 & 66.33 & 3.21 & 3.35 & 193.10 & 222.03 & 2.05 & 2.35 \\
\hline \multirow{3}{*}{6} & 100 & 64.00 & 71.67 & 3.91 & 3.91 & 249.88 & 280.05 & 2.65 & 2.97 \\
\hline & 150 & 66.67 & 74.00 & 4.05 & 4.15 & 270.08 & 307.25 & 2.86 & 3.26 \\
\hline & 200 & 70.67 & 75.00 & 4.12 & 4.23 & 290.78 & 317.45 & 3.08 & 3.36 \\
\hline \multicolumn{10}{|c|}{ L.S.D at $5 \%$ for } \\
\hline \multicolumn{2}{|c|}{ Humic acid } & 1.57 & 1.44 & 0.26 & 0.10 & 13.75 & 9.82 & 0.09 & 0.10 \\
\hline \multicolumn{2}{|l|}{ Chitosan } & 1.35 & 1.02 & 0.20 & 0.07 & 11.83 & 7.64 & 0.08 & 0.10 \\
\hline \multicolumn{2}{|l|}{ Interaction } & 2.69 & N.S. & N.S. & 0.14 & N.S. & 15.29 & 0.15 & 0.19 \\
\hline
\end{tabular}


The interaction between humic acid and chitosan levels indicated that the application of $6 \mathrm{~kg}$ humic acid/fed combined with $200 \mathrm{ppm}$ chitosan recorded the highest number of fruits/plant, mean fresh weight of fruit, plant yield and total yield per feddan. The lowest values were recorded by no humic acid application combined with no chitosan application treatment, in both seasons. The differences among treatments were significant in both seasons, except number of fruits/plant in the second season, mean fresh weight of fruit and plant yield in the first season.

The satisfactory influence of using the humic acid and chitosan applications on fruit yield and its components may be due its favorable effect on plant growth (Table 3) and percentages of leaf minerals (Table 4).

\section{Nutritional Status of Fruit}

Data presented in table (6) indicated that total protein, $\mathrm{P}$ and $\mathrm{K}$ percent were significantly increased with increasing of humic acid applications as compared to the control in both seasons. Our results are in agreement with those of Rizk et al. (2013) and Kandil et al. (2015). On the other hand, percent of dietary fiber in fruits was reduced gradually by increasing humic acid levels in both growing seasons. Similar finding were reported by El Bassiony et al. (2010). The favorable effect of humic acid on increasing total protein, $\mathrm{P}$ and $\mathrm{K}$ percent in fruit may be due to favorable effect on leaf mineral contents (Table 4).

Chitosan levels had significant effect on nutritional status of okra fruit (Table 6). In general, there were gradual increments in fruit total protein, phosphorus and potassium values with increasing the chitosan level. While, dietary fiber was decreased with increasing the chitosan level in both seasons. The same trend was reported by Shehata et al. (2012) and Abu Muriefah (2013). This result may be due to the effect of chitosan on leaf minerals (Table 4).

Regarding the effect of interaction between humic acid and chitosan level on nutritional status of okra fruits, i.e., total protein, phosphorus, potassium and dietary fiber contents, there were significant differences among treatments in both seasons except dietary fiber in the first season, phosphorus and potassium in the second season. Application of $6 \mathrm{~kg}$ humic acid/fed combined with $200 \mathrm{ppm}$ chitosan gave the highest values of total protein, phosphorus, potassium, and the lowest values of dietary fiber in both seasons. 
Table (6). Effect of humic acid and chitosan on nutritional status of fruit (total protein, dietary fiber, P and K \%) of okra plants in 2013 and 2014 seasons.

\begin{tabular}{|c|c|c|c|c|c|c|c|c|c|}
\hline \multicolumn{2}{|c|}{ Treatments } & \multirow{2}{*}{\multicolumn{2}{|c|}{ Total protein }} & \multirow{2}{*}{\multicolumn{2}{|c|}{ Dietary fiber }} & \multirow{2}{*}{\multicolumn{2}{|c|}{$\mathbf{P}$}} & \multirow{2}{*}{\multicolumn{2}{|c|}{$\mathbf{K}$}} \\
\hline \multirow{2}{*}{$\begin{array}{c}\text { Humic } \\
\text { acid } \\
\text { (kg/fed) }\end{array}$} & \multirow{2}{*}{$\begin{array}{c}\text { Chitosan } \\
\text { (ppm) }\end{array}$} & & & & & & & & \\
\hline & & 2013 & 2014 & 2013 & 2014 & 2013 & 2014 & 2013 & 2014 \\
\hline $\mathbf{0}$ & & 3.52 & 3.66 & 2.29 & 2.39 & 0.46 & 0.55 & 2.02 & 2.13 \\
\hline 2 & & 3.68 & 3.79 & 1.92 & 2.31 & 0.47 & 0.60 & 2.41 & 2.38 \\
\hline 4 & & 3.80 & 3.96 & 1.83 & 2.21 & 0.58 & 0.69 & 2.47 & 2.52 \\
\hline \multirow[t]{6}{*}{6} & & 4.09 & 4.24 & 1.70 & 1.95 & 0.69 & 0.77 & 2.59 & 2.72 \\
\hline & $\mathbf{0}$ & 3.58 & 3.65 & 2.17 & 2.35 & 0.46 & 0.56 & 2.07 & 2.20 \\
\hline & 100 & 3.73 & 3.88 & 2.00 & 2.24 & 0.51 & 0.63 & 2.29 & 2.37 \\
\hline & 150 & 3.86 & 4.00 & 1.83 & 2.18 & 0.58 & 0.68 & 2.52 & 2.52 \\
\hline & 200 & 3.93 & 4.12 & 1.74 & 2.10 & 0.65 & 0.74 & 2.62 & 2.66 \\
\hline & $\mathbf{0}$ & 3.38 & 3.41 & 2.57 & 2.44 & 0.41 & 0.48 & 1.93 & 2.04 \\
\hline \multirow{4}{*}{$\mathbf{0}$} & 100 & 3.45 & 3.66 & 2.40 & 2.40 & 0.43 & 0.53 & 1.96 & 2.07 \\
\hline & 150 & 3.55 & 3.75 & 2.17 & 2.38 & 0.45 & 0.56 & 2.07 & 2.18 \\
\hline & 200 & 3.69 & 3.80 & 2.03 & 2.35 & 0.53 & 0.64 & 2.13 & 2.24 \\
\hline & $\mathbf{0}$ & 3.49 & 3.56 & 2.16 & 2.41 & 0.43 & 0.54 & 2.05 & 2.12 \\
\hline \multirow{4}{*}{2} & 100 & 3.68 & 3.75 & 1.95 & 2.32 & 0.45 & 0.57 & 2.30 & 2.29 \\
\hline & 150 & 3.75 & 3.88 & 1.85 & 2.28 & 0.47 & 0.61 & 2.57 & 2.48 \\
\hline & 200 & 3.80 & 3.96 & 1.73 & 2.22 & 0.54 & 0.66 & 2.73 & 2.62 \\
\hline & $\mathbf{0}$ & 3.60 & 3.74 & 2.08 & 2.33 & 0.46 & 0.57 & 2.09 & 2.22 \\
\hline \multirow{4}{*}{4} & 100 & 3.79 & 3.89 & 1.86 & 2.26 & 0.51 & 0.66 & 2.33 & 2.44 \\
\hline & 150 & 3.90 & 3.99 & 1.71 & 2.18 & 0.63 & 0.74 & 2.68 & 2.61 \\
\hline & 200 & 3.92 & 4.23 & 1.65 & 2.07 & 0.70 & 0.78 & 2.78 & 2.79 \\
\hline & $\mathbf{0}$ & 3.83 & 3.90 & 1.86 & 2.21 & 0.52 & 0.65 & 2.20 & 2.42 \\
\hline \multirow{3}{*}{6} & 100 & 3.99 & 4.20 & 1.77 & 1.98 & 0.65 & 0.76 & 2.57 & 2.67 \\
\hline & 150 & 4.24 & 4.36 & 1.60 & 1.86 & 0.76 & 0.80 & 2.76 & 2.81 \\
\hline & 200 & 4.31 & 4.50 & 1.55 & 1.74 & 0.81 & 0.86 & 2.84 & 2.97 \\
\hline \multicolumn{10}{|c|}{ L.S.D at $5 \%$ for } \\
\hline \multicolumn{2}{|c|}{ Humic acid } & 0.04 & 0.05 & 0.09 & 0.03 & 0.03 & 0.03 & 0.09 & 0.17 \\
\hline \multicolumn{2}{|c|}{ Chitosan } & 0.04 & 0.04 & 0.06 & 0.02 & 0.02 & 0.03 & 0.08 & 0.12 \\
\hline \multicolumn{2}{|c|}{ Interaction } & 0.07 & 0.09 & N.S. & 0.04 & 0.04 & N.S. & 0.16 & N.S. \\
\hline
\end{tabular}

\section{CONCLUSION}

In conclusion, the effects of humic acid and chitosan application are safe and as a result, it is effective and easily adopted by farmers. The study assumes that humic acid and chitosan play a major role in plant growth, nutrient uptake and productivity of plants. The results of this study showed

Egyptian J. Desert Res., 65, No. 1, 47-60 (2015) 
that humic acid and chitosan have a great potential to increase the growth, mineral contents and yield of okra plant El Balady cultivar.

Finally, it could be concluded that the application of $6 \mathrm{~kg}$ humic acid/fed combined with 200 ppm chitosan reduced the harmful effect of salinity on okra plants under saline soil condition.

\section{REFERENCES}

Abd El Gawad, H.G. and A.M. Bondok (2015). Response of tomato plants to salicylic acid and chitosan under infection with tomato mosaic virus. AEJAES, 15 (8): 1520-1529.

Abdel-Mawgoud, A.M.R, A.S. Tantawy, M.A. El-Nemr and Y.N. Sassine (2010). Growth and yield responses of strawberry plants to chitosan application. EJSR, 39 (1): 161-168.

Abu Muriefah, S.S. (2013). Effect of chitosan on common bean (Phaseolus vulgaris L.) plants grown under water stress conditions. IRJAS, 3 (6): 192-199.

Abu Zinada, I.A. and K.S. Sekh Eleid (2015). Humic acid to decrease fertilization rate on potato (Solanum tuberosum L.). Amer. J. Agric. and Forestry, 3 (5): 234-238.

Al-ahmadi, M.S. (2015). Cytogenetic effect of chitosan on mitotic chromosomes of root tip cells of Vicia faba. Life Sci. J., 12 (2): 158162.

A.O.A.C. (1995). In "Method of Analysis". Association of Official Agriculture Chemists. 16th Ed., Washington, D.C., USA.

Ashraf, M., M. Arfan and A. Ahmad (2003). Salt tolerance in okra: ion relations and gas exchange characteristics. J. Plant Nutr., 26 (1): 6379.

Bama, K.S., G. Selvakumari, R. Santhi and P. Singaram (2003). Effect of humic acid on nutrient release pattern in an Alfisol (Typic Haplustalf). Madras Agric. J., 90 (10-12): 665-670.

Black, C. and A. Editor (1965). In "Methods of Soil Analysis". Part 1 and 2. Amer. Soc. Agron. Inc., Pub. Madison, Wisconison, U.S.A .

Bolot, B., D. Dixon and R. Eldridge (2004). Ion exchange for the removal of natural organic matter. React. Funct. Poly., 60: 171-182.

Chapman, H.D. and P.F. Pratt (1982). In "Methods of Plant Analysis". I. Methods of Analysis for Soil, Plant and Water. Chapman Publishers, Riverside, California, USA.

Chibu, H. and H. Shibayama (2003). In "Effects of Chitosan Application on the Growth of Several Crops". Chitin and Chitosan in Life Science. T. Uragami, K Kurita, and T. Fukamizo (eds.). Yamaguchi, Japan. p. 235-239.

Cottenie, A.L. (1980). Soils and plant testing as a basis of fertilizer recommendation. FAO Soil Bull., 3812.

Egyptian J. Desert Res., 65, No. 1, 47-60 (2015) 
Eid, M.A. (2011). Effect of mineral and organic nitrogen fertilization and Khumate addition on soil properties (Orchard field experiment). J. Am. Sci., 7 (5): 1014-1022.

El-Bassiony, A.M., Z.F. Fawzy, M.M.H. Abd El Baky and Asmaa R. Mahmoud. (2010). Response of Snap Bean plants to mineral fertilizers and humic acid application. Res. J. Agric. and Biol. Sci., 6 (2):169175.

El Hefny, Eslah M. (2010). Effect of saline irrigation water and humic acid application on growth and productivity of two cultivars of cowpea (Vigna unguiculata L. Walp). Aust. J. Basic and Appl. Sci., 4 (12): 6154-6168.

Falk, M., D.G. Smith, J. Mclachland and A.G. Mclnnes (1966). Studies on chitin (9-(1-14) Linked 2-acetamido-2-deoxy-D-glucan) fibres of the diatom Thalassiosira fluviatilis Husted. Can. J. Chem., 44: 2269-81.

Farnia, A. and E. Moradi (2015). Effect of soil and foliar application of humic acid on growth and yield of tomato (Lycopersicon esculentum L.). IJBPAS, 4 (10): 706-716.

Gornik, K., M. Grzesik and B.R. Duda (2008). The effect of chitosan on rooting of gravevine cuttings and on subsequent plant growth under drought and temperature stress. J. Fruit Ornamental Plant Res., 16: 333-343.

Guan, Y., H. Jin, W. Xian-ju and S. Chen-xia (2009). Seed priming with chitosan improves maize germination and seedling growth in relation to physiological changes under low temperature stress. JZUS, 10 (6): 427-433.

Hossain, M.S., M.M. Rahman, M.R. Rashid, A.T.M. Farid, M.A. Kaium, M. Ahmed, M.S. Alam and K.M.S. Uddin (2006). In "Handbook on Agro technology". $4^{\text {th }}$ ed., Bangladesh Agricukltural Res. Inst., Gazipur1701, Bangladesh, p. 356-358.

Jackson, M.L. (1967). In "Soil Chemical Analysis". Printie-Hall of India Private New Delhi, India.

Kandil, H., N. Gad and M.R. Abed El Moez (2015). Response of okra (Hibiscus esculantus) growth and productivity to cobalt and humic acid rates. Int. J. Chem. Tech. Res., 8 (4): 1782-1791.

Khaled, H. and H.A. Fawy (2011). Effect of different levels of humic acids on the nutrient content, plant growth, and soil properties under conditions of salinity. Soil and Water Res., 6 (1): 21-29.

Khan W.M, B. Prithiviraj and D.L. Smiyh (2002). Effect of foliar application of chitin oligosaccharides on photosynthesis of maize and soybean. Photosynthetica, 40: 621-624.

Khristeva, L.A. (1953). The participation of humic acids and other organic substances in the nutrition of higher plants. Pochvovedenie, 10: 46-59.

Egyptian J. Desert Res., 65, No. 1, 47-60 (2015) 
Mondal, M.M.A., M.A. Malek, A.B. Puteh, M.R. Ismail, M. Ashrafuzzaman and L. Naher (2012). Effect of foliar application of chitosan on growth and yield in okra. AJCS, 6 (5): 918-921.

Ozkutlu, F., B. Torun and I. Cakmak (2006). Effect of zinc humate on growth of soybean and wheat in zinc deficient calcareous soil. Communi. in Soil Sci. and Plant Ana., 37 (15): 2769 -2778.

Richards, L.A. (1954). In "Diagnosis and Improvement of Saline and Alkali Soils". U. S. Dept. Agric. Handbook, 60: 160.

Rizk, F.A, A.M. Shaheen, S.M. Singer and Ommima A. Sawan (2013). The productivity of potato plants affected by urea fertilizer as foliar spraying and humic acid added with irrigation water. Middle East $\mathbf{J}$. Agric. Res., 2 (2): 76-83.

Samashekar, D. and R. Joseph (1996). Chitosanase properties and application: A review. Bioresour. Technol., 55: 35-45.

Senesi N., T.M. Miano and G. Brunetti (1996). In "Humic-Like Substances in Organic Amendments and Effects on Native Soil Humic Substances". Piccolo, A. (ed.). Humic Substances in Terrestrial Ecosystems. USA, New York: Elsevier, p. 531-593.

Shafeek, M.R., A.H. Ali, A.R. Mahmoud, M.M. Hafez and F.A. Rizk (2015). Improving growth and productivity of garlic plants (Allium sativum L.) as affected by the addition of organic manure and humic acid levels in sandy soil conditions. Int. J. Curr. Microbiol. App. Sci., 4 (9): 644-656.

Sharif, M. (2002). Effect of lignitic coal derived humic acid on growth and yield of wheat and maize in alkaline soil. Ph.D. Thesis, Soil and Environmental Sciences Dept., Faculty of Crop Production Sciences, NWFP Agric. Univ.

Shehata, S.A., Z.F. Fawzy and H.R. El-Ramady (2012). Response of cucumber plants to foliar application of chitosan and yeast under greenhouse conditions. Aust. J. Basic and Appl. Sci., 6 (4): 63-71.

Steel, G.D.R. (1960). In "Principles and Procedures of Statistics". New York McGraw-Hill Book Co., 481 pp.

Sugiyama, H., K. Hisamichi, K. Sakai, T. Usui, J.J. Shiyama, H. Kudo, H. Ito and Sei (2001). The conformational study of chitin and chitosan oligomers in solution. J. Bioorg. Med. Chem., 9: 22112216. 
تأثير حض الهيوميك والثيتوسان على نمو ومحصول الباميا تحت الظروف

منصور السيد رمضان* وعحم مصطفى عبد المجيد المسيري

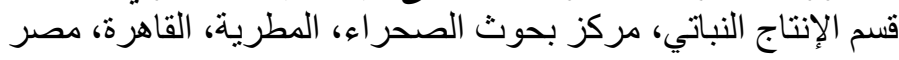

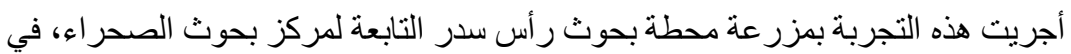

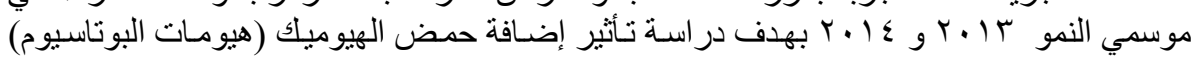

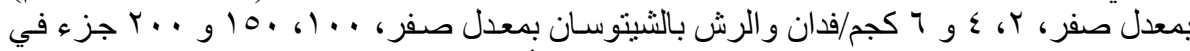

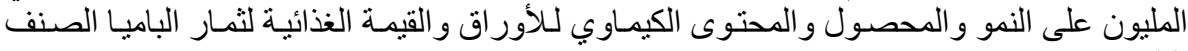

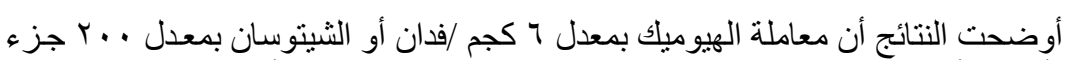

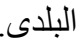

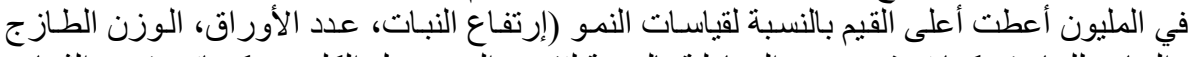

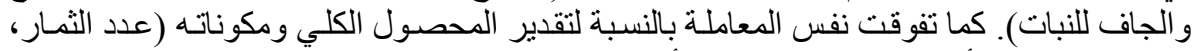

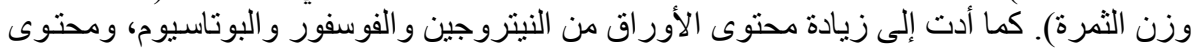

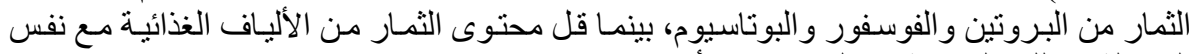

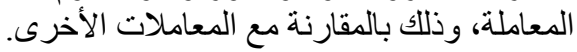

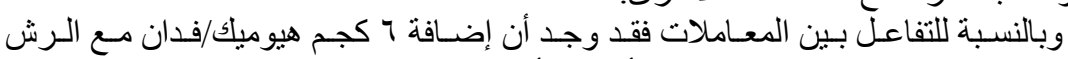

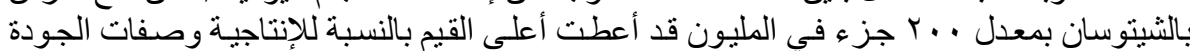

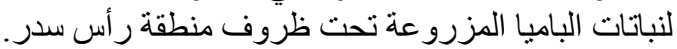

Egyptian J. Desert Res., 65, No. 1, 47-60 (2015) 